UDC 35.088 .6

S. Rudenko ${ }^{1}$, Dr. Sc. (Philos.), Prof., orcid.org/0000-0001-9069-0989, O. Bazaluk ${ }^{1}$, Dr. Sc. (Philos.), Prof., orcid.org/0000-0002-1623-419X, V. Tsvykh ${ }^{1}$, Dr. Sc. (Polit.), Prof., orcid.org/0000-0003-3106-7454,

I. Kalmuk ${ }^{1,2}$, Cand. Sc. (Philos.), Assoc. Prof., orcid.org/0000-0001-5374-209X
DOI: $10.29202 /$ nvngu/2019-3/22

1 - Taras Shevchenko National University of Kyiv, Kyiv, Ukraine, e-mail: rudenkosrg@gmail.com

2 - Kyiv University of Law NAS of Ukraine, Kyiv, Ukraine, e-mail: kalmukip@gmail.com

\title{
THE ROLE OF PHILOSOPHICAL DISCIPLINES IN EDUCATIONAL STRATEGIES FOR SPECIALIST TRAINING IN THE FIELD OF PUBLIC ADMINISTRATION
}

Purpose. To reveal the optimal model for the functioning of philosophical disciplines in the structure of educational programs for specialist training in "Public administration" specialty, as well as the specific features of managing the educational strategies for civil servants training. The authors focus on: 1) the ways of administrative solution of the problem of oversaturation of educational programs in the field of public administration with a set of philosophical disciplines; 2) the adaptation of educational programs for specialist training in the field of public administration to the needs of national and international employers; 3 ) the peculiarities of the internationalization of educational programs in the field of public administration in the context of academic mobility and the adaptation of the public administration system of Ukraine to the European Union standards.

Methodology. The authors used the method of cultural-historical analysis, the comparative method, the structural-functional method, as well as the expert evaluation method.

Findings. An organizational model of functioning of philosophical disciplines in the structure of educational programs for specialist training in the field of public administration is proposed; according to this model the historical and philosophical disciplines, the set of theoretical and practical philosophy taught in the Ukrainian language, are replaced with the English-language courses of logic, theory of argumentation, applied political science and applied culturology. The authors singled out and examined the peculiarities of the management of educational strategies for civil servants training in Ukraine, which are related to the place and functions of philosophical disciplines and nowadays require special attention:

1) the oversaturation of educational programs with historical and philosophical disciplines, as well as the disciplines of theoretical and practical philosophy in the conditions of unsatisfied needs for the formation of general competencies;

2) the need to adapt educational programs for specialist training in the field of public administration to the needs of national and international employers without losing the advantages of classical university education;

3 ) the usage of English to teach disciplines of logical, political and cultural cycles aimed at the formation of general competencies.

Originality. The practical model of functioning of philosophical disciplines and the socio-humanitarian disciplines in the structure of educational programs for specialist training in "Public Administration" specialty adapted to the modern national and international conditions has been developed, which allows increasing the efficiency and competitiveness of higher education in Ukraine in the field of public administration, integrate training of civil servants and managers in Ukraine in the international educational and scientific space, creating conditions for the adaptation of Ukraine's institutional and non-institutional management practices to the European Union standards.

Practical value. The usage of the results obtained in the educational practice of the Ukrainian universities, which train specialists in "Public Administration" specialty, allows improving the quality of higher education, as well as finding the optimal solution to the problem of the correlation between fundamental and highly specialized components of civil servants and managers training.

Keywords: public administration, philosophical disciplines, higher education in Ukraine, managers training, internationalization of higher education in Ukraine

Introduction. In the article, the authors use personal managerial experience in organizing, managing and implementing educational strategies, educational programs for specialist training in "Public Administration" specialty at Taras Shevchenko National University of Kyiv at the first, second and third levels of higher educa-

(C) Rudenko S., Bazaluk O., Tsvykh V., Kalmuk I., 2019 tion; analyze typical managerial problems related to the functioning of philosophical disciplines as a way to ensure the general competencies of specialists in the field of public administration, and offer solutions to these problems on the basis of practical experience of cooperation with national and international employers, as well as the experience mentioned in international scientific publications on the stated theme. 
Basing on the practical experience of cooperation with national and international employers, as well as the experience recorded in international scientific publications on the stated topic (for example, [1]), the authors identify the main, from their point of view, management problems, as well as offer solutions to them.

Literature review. While analyzing the features of the functioning of philosophical disciplines in educational strategies and educational programs in general, as well as specialist training in public administration, the authors used research studies by O. Bazaluk [2], V. Vilkov [3], D. Svyrydenko [4], I. Liashenko [5], Y. Sobolievskyi [6], V. Tytarenko [7], and others. The research works of these authors are the most modern and authoritative in this field.

The studies of these authors are based on practical experience, which includes creation of joint educational centers between the leading Ukrainian public universities and universities of Central Europe; authoritative non-governmental international scientific organizations; publication of reputable international scientific journals; participation in international European grants and other interstate projects.

Results. Philosophy and philosophical disciplines play a key role in providing general competencies in the system of university education. The importance of philosophy, philosophical disciplines, and common cultural competencies in general in the process of specialist training in "Public administration" specialty is of obvious value, which does not require additional explanations and proofs. In the article "Strategy, managerial model and educational and scientific program for training civil servants in the university postgraduate school" the authors have already considered this issue on the example of training civil servants in the postgraduate school of Taras Shevchenko National University of Kyiv [8]. According to the authors, the article by R. Naumenko "Management for the Society of the Future: New Trends in the Training for Civil Servants in Ukraine", in which the author considers new tendencies in the training for civil servants in Ukraine [9], also deserves attention.

At the same time, in our opinion, the post-soviet practices and models of understanding and, accordingly, teaching philosophy and philosophical disciplines, as well as socio-humanitarian disciplines as a whole, take place in modern educational and scientific space of Ukraine. Particularly unacceptable and generating managerial problems is the post-soviet practice of positioning philosophical and socio-humanitarian disciplines as key ones in educational strategies and educational programs in the Ukrainian university education. This is indicated by a number of modern authors, for example, P. Sodomora [10], S. Yosypenko [11] and others. In the article "Philosophy and Post-Totalitarian Practices" S. Yosypenko tried to identify correlations between philosophy and the phenomenon of totalitarianism, as well as to consider the methodological and axiological problems of the study of post-totalitarian practices in philosophy, which, according to the author, caused "cynicism" and "nihilism" of post-Soviet philosophy [11].
Obviously, this approach leads to a decrease in the quality of educational program, its competitiveness in the national market and international one, as well as a decrease in the interest of national and international entrants. These problems are especially evident in the field of university specialist training in public administration.

If we use the terminology of O. Bazaluk [2], in modern education there are two competing models of understanding and positioning philosophy and philosophical disciplines, which the researcher calls the "Plato's line" and the "Isocrates' line". The main difference between these two lines is the way in which philosophies is applied in education. If the former perceives the function of philosophy in the formation of the personality and his worldview and asks the question "Who should be educated?", the latter understands philosophy not as an ideology or worldview, but rather as an effective tool in the education system ("How to educate?") [2].

In our opinion, domination of understanding philosophy and philosophical disciplines in the style of the "Plato's line" (as a worldview) in the Ukrainian system of specialist training in the field of public administration is one of the factors that generate the above-described managerial and strategic problems. Understanding philosophy and philosophical disciplines as an effective auxiliary tool continues to be insufficiently developed in educational strategies and training programs for civil servants and managers.

The development of this approach requires analysis, in our opinion, of the three most relevant for Taras Shevchenko National University of Kyiv peculiarities of organization and management of educational programs for specialist training in "Public Administration" specialty. Let us single out these three features and propose options for their management solution:

1. The oversaturation of educational programs on public administration with philosophical disciplines of historical-philosophical and theoretical contents in the context of the unmet need for the formation of general competencies.

2. The need to adapt educational programs for specialist training in the field of public administration to the needs of national and international employers without losing the advantages of classical university education.

3. Inadequate usage of English to provide disciplines of logical, political and cultural cycles aimed at the formation of general competencies.

Options for their management solution.

1. The oversaturation of educational programs on public administration with philosophical disciplines of historical-philosophical and theoretical contents in the context of the unmet need for the formation of general competencies. The essence of this feature is that the formation of such general competencies as existence of a systematic scientific worldview, a professional ethics, a broad cultural outlook, an ability to re-think the existing and create new knowledge, an ability to understand and solve the complex problems of the development of science, society and culture in educational practice is now erroneously, from our point of view, laid on a number of his- 
torical and philosophical disciplines ("History of Ancient Philosophy", "Philosophy of the Middle Ages and Renaissance", "History of Modern Philosophy", etc.), and a number of disciplines of theoretical and practical philosophy ("Metaphysics and Ontology", "Epistemology", "Philosophy and Methodology of Science", "Philosophical Anthropology", "Philosophy of Culture", "Philosophy of History", "Social Philosophy", "Political Philosophy", "Ethics", "Aesthetics", etc.). In curricula, these disciplines can be presented in combined or differentiated forms with different budgets of time; however, this does not change the essence of the problem.

The availability of these general competencies for specialists in the field of public administration does not raise any doubts; however, we consider erroneous the managerial vision of the history of philosophy and theoretical philosophy as a source of formation of these general competencies for specialists in the field of public administration. In other words, the above philosophical disciplines are special in their content and form; therefore, in educational practice they do not lead to the acquisition of the necessary general competencies. Moreover, being objectively complex for students of nonphilosophical specialties, these disciplines generate misunderstanding, and sometimes, negative attitude of students towards organization of the educational process.

It should be noted that the described situation did not arise spontaneously, yet was formed in the system of higher education of Ukraine under the influence of a number of historical factors and educational traditions. Their peculiarity lies in the fact that in the Soviet model of the work of the Philosophy Faculty of Kyiv University (which at that time also trained managers for public authorities) the division into specialties ("Dialectical Materialism", "Scientific Communism", "Scientific Atheism", etc.) actually began during the third year of training. During the first four semesters students studied the same set of historical, philosophical and theoretical disciplines.

The managerial solution of this problem, in our opinion, is the replacement in the structure of educational programs for specialist training in public administration of historical, philosophical and theoretical disciplines with:

a) a logical cycle in the focus of forming the skills of critical and analytical thinking, theory and practice of argumentation, practical rhetoric, influence in business communication;

b) a culturological cycle in understanding of cultural studies as a managerial and communicative practice;

c) a political cycle in the aspect of applied political science.

These disciplines, being philosophical in their content and origin, in our opinion, represent philosophical knowledge not as a worldview ("Plato's line"), but as a necessary and effective tool ("Isocrates's line"), represented in the form of general competencies for the future professional practices of civil servants and managers. This approach allows presenting general competence as specifically and obviously applicable one. In the practice of organizing the educational process in "Public administration" specialty introduction of the mentioned disciplines demonstrates considerable effectiveness and receives positive feedback from students and other participants in the educational process.

2. The need to adapt educational programs for specialists training in the field of public administration to the needs of national and international employers without losing the advantages of classical university education. The essence of this feature is that educational programs for specialist training in the field of public administration are well coordinated with the needs of employers at the level of special competencies and not sufficiently coordinated at the level of general competencies [12]. The practice of cooperation with employers shows that the general competencies necessary for the employer are not formed in the university academic environment, but in the workplace, which is quite unusual. In the process of interaction between the university and the employer, there is a danger of losing the advantages of classical university education, because quite often employers, when observing the way of forming general competencies through philosophical disciplines, doubt its value and effectiveness. This feature is especially evident in the process of cooperation with international employers and foreign partner universities when planning and organizing common educational programs, academic mobility programs, etc.

The managerial solution of the described problem of organization of educational programs in "Public Administration" specialty, in our opinion, is the practice of agreeing with employers and foreign partner universities not only the special competencies and skills of a future graduate, yet also general competencies. As an example, we can give the cooperation of the Philosophy Faculty of Taras Shevchenko National University of Kyiv with the Humanities Faculty of the University of Zielona Gora, the largest public educational institution in Lubusz Voivodeship (Zielona Góra, Poland). The result of the cooperation was the creation of a joint educational center in 2017. Thanks to the Centre activities, there were achieved:

a) harmonization of management practices in the field of higher education and science in Ukraine and Poland, which ensured the successful implementation of joint research and educational projects;

b) adaptation of joint educational programs to the needs of employers;

c) development of language communication in humanitarian specialties;

d) attracting non-governmental educational and scientific organizations for the implementation of joint scientific and educational projects.

The effective cooperation on the scale of the created Centre allowed us not only to compare and discover the difference in educational programs for training specialists in the field of public administration in Ukraine and Poland, but also to work out concrete steps to adapt the Ukrainian educational programs to the needs of international employers, without losing the benefits of classi- 
cal university education. Thanks to the work of the Centre, a significant difference in understanding of the statements of the Bologna declaration in Ukraine and Poland was found. Unification of higher education in Ukraine, which is held under the slogan of the need to integrate the Ukrainian education system into the European higher education area (EHEA), differs significantly from the vision of a single European educational area in Poland [13]. The principal difference is that integration is considered not as a formal process, but as an effective reorganization of the Polish universities in accordance with the experience of leading universities in $\mathrm{Eu}-$ rope and the world. The emphasis is on shaping the general competencies of students, which open up opportunities for intercultural communication in the European area [14].

3. Inadequate usage of English to provide disciplines of logical, political and cultural cycles aimed at the formation of general competencies. The essence of this feature is that formation of the English competence in modern educational practice of specialist training in the field of public administration is carried out at the level of general knowledge of the language (General English) within the appropriate training course provided by the language department of the university and at the level of special training courses within the chosen specialty. At first glance, this situation seems reasonable; however, in educational practice of civil servants training, it forms a gap between the general language culture and the skills of using English in professional sphere. This gap is often expressed in the inconsistency of curricula in general English with special courses that are taught in English.

Without questioning the need for general language training, we believe that the most effective way to build competence in English is to study it in the framework of training courses aimed at building general competencies. The practice of teaching disciplines of logical, culturological and political science cycles in English makes it possible to avoid a gap between the philological environment in which the student must immerse himself/ herself when provided with a discipline by the language department and the professional environment for real language usage. This model, although not yet sufficiently developed, ensures continuity of study and practice of the English language within the entire educational program of manager training.

Conclusions. Summing up our research, we should note that philosophical disciplines as a source of formation of general competencies play a key role in formation of modern educational strategy and effective educational programs for university specialist training in the field of public administration [15]. However, the practice of using the philosophical disciplines of the historical, philosophical and theoretical cycles to form the general competencies of the future manager is obsolete and should be revised in favor of logical, cultural and political science disciplines [16].

The authors singled out and examined three problematic aspects of the organization and functioning of philosophical disciplines in the structure of university educational programs in "Public administration" specialty, which require special attention:

1. Oversaturation of educational programs for public administration with philosophical disciplines of the historical, philosophical and theoretical cycles in the unmet need for the formation of general competencies.

2. The need to adapt educational programs for specialist training in the field of public administration to the needs of national and international employers without losing the advantages of classical university education.

3. Inadequate usage of English to provide disciplines of logical, political and cultural cycles aimed at the formation of general competencies.

The authors suggested solutions to these management problems, which, from our point of view, can improve the quality of higher education in Ukraine in "Public Administration" specialty. The authors emphasized the special role of integrating of formation of English language competencies within the philosophical disciplines of the logical, culturological and political science cycles.

\section{References}

1. Rudenko, S., Sapenko, R., Bazaluk, O., \& Tytarenko, V. (2018). Management Features of International Educational Projects between Universities of Poland and Ukraine. Naukovyi Visnyk Natsionalnoho Hirnychoho Universytetu, 2(164), 142-147. DOI: 10.29202/nvn$\mathrm{gu} / 2018-2 / 21$.

2. Bazaluk, O. (2018). The Feature Transformations of the Basic Meanings of Greek Paideia in the Educational Theories in the Middle Ages. Schole, 12.1, 243-258. DOI: 10.21267/AQUILO.2018.12.10428.

3. Vilkov, V. (2018). Scientific Communism" and the Modern Political Science in Ukraine. Ukrainian Policymaker, 2, 48-55. DOI: 10.29202/up/2/7.

4. Svyrydenko, D. (2016). Mobility Turn in Contemporary Society as an Educational Challenge. Future $\mathrm{Hu}$ man Image, 3(6), 102-108.

5. Liashenko, I. (2018). Wilhelm Dilthey: Understanding the Human World. Philosophy and Cosmology, 20, 163-169. DOI: 10.29202/phil-cosm/20/16.

6. Sobolievskyi, Y. (2018). Soviet and Ukrainian Studies of American Philosophy: Translation of Philosophical Texts. Future Human Image, 9, 100-106. DOI: 10.29202/ fhi/9/10.

7. Tytarenko, V., \& Rudenko, S. (2018). Kant's Studies in Ukrainian Philosophy of Soviet Period. Future $\mathrm{Hu}$ man Image, 9, 107-114. DOI: 10.29202/fhi/9/11.

8. Nelipa, D., \& Batrymenko, O. (2018). Strategy, management model and educational scientific civil servants training program in postgraduate studies of the university. Naukovyi Visnyk Natsionalnoho Hirnychoho Universytetu, 1(164), 178-183. DOI: 10.29202/nvngu/2018$2 / 16$.

9. Naumenko, R. (2017). Management for the Society of the Future: New Trends in the Training for Civil Servants in Ukraine. Philosophy and Cosmology, 19, 117-125. 10. Sodomora, P. (2018). Ukrainian Philosophical Thought at the Brink between East and West. Ukrainian Policymaker, 3, 65-71. DOI: 10.29202/up/3/9. 
11. Yosypenko, S. (2018). Philosophy and Post-Totalitarian Practices. Future Human Image, 9, 134-144. DOI: 10.29202/fhi/9/14.

12. Nelipa, D., Batrymenko, O., Rudenko, S., \& Liashenko, I. (2018). Higher Educational Management in Ukraine: will generation change help us transform it faster? Naukovyi Visnyk Natsionalnoho Hirnychoho Universytetu, 3(165), 167-175. DOI: 10.29202/nvngu/2018$3 / 19$.

13. Czyz, A. (2018). An Analysis of Polish Teachers Attitudes towards Inclusive Education. Future Human Image, 10, 4-19. DOI: 10.29202/fhi/10/1.

14. Sakun, A., \& Mordous, I. (2019). Digital Re-Evolution: Learning to be Human at Contemporary Society. Philosophy and Cosmology, 22, 129-136. DOI: 10.29202/ phil-cosm/22/11.

15. Kravchenko, A., \& Kyzymenko, I. (2019). The Forth Industrial Revolution: New Paradigm of Society Development or Posthumanist Manifesto. Philosophy and Cosmology, 22, 120-128. DOI: 10.29202/phil-cosm/ 22/10.

16. Yakushik, V. (2018). Varieties of a Law-Governed State. Ukrainian Policymaker, 3, 72-84. DOI: 10.29202/ up $/ 3 / 10$.

\section{Роль філософських дисциплін в освітніх стратегіях підготовки фахівців у галузі публічного адміністрування}

\author{
С. В. Руденко ${ }^{1}$, О. О. Базалук ${ }^{1}$, В.Ф. Цвих ${ }^{1}$, \\ I. П. Кальмук $\kappa^{1,2}$
}

1 - Київський національний університет імені Тараса Шевченка, м. Київ, Україна, e-mail: rudenkosrg@gmail. com

2 - Київський університет права НАН України, м. Київ, Україна, e-mail: kalmukip@gmail.com

Мета. Розкрити оптимальну модель функціонування філософських дисциплін у структурі освітніх програм підготовки фахівців за спеціальністю „Публічне управління та адміністрування“, а також пов'язані 3 цим аспектом особливості управління освітніми стратегіями підготовки державних службовців. Автори акцентують увагу на: 1) способах управлінського рішення проблеми перенасиченості освітніх програм у галузі публічного управління та адміністрування блоком філософських дисциплін; 2) адаптації освітніх програм підготовки фахівців у галузі публічного адміністрування до потреб національних і міжнародних роботодавців; 3) особливості інтернаціоналізації освітніх програм у галузі публічного адміністрування в контексті академічної мобільності та адаптації системи публічного адміністрування України до стандартів Европейського Союзу.

Методика. Автори використовували метод культурно-історичного аналізу, порівняльний метод, структурно-функціональний метод, а також метод експертної оцінки.

Результати. Запропонована організаційна модель функціонування філософських дисциплін у структурі освітніх програм підготовки фахівців у галузі публічного адміністрування, згідно з якою дисципліни історико-філософського напряму, блоку теоретичної та практичної філософіі, що викладаються українською, замінюються англомовними навчальними курсами блоків логіки, теорії аргументації, прикладної політології та прикладної культурології. Автори виділили й розглянули пов'язані з місцем і функціями філософських дисциплін особливості управління освітніми стратегіями підготовки державних службовців в Україні, що в даний час потребують особливої уваги:

1) перенасиченість освітніх програм історикофілософськими дисциплінами, а також дисциплінами галузі теоретичної та практичної філософії в умовах незадоволеної потреби формування загальних компетентностей;

2) необхідність адаптації освітніх програм підготовки фахівців у галузі публічного управління та адміністрування до потреб національних і міжнародних роботодавців без втрати переваг класичної університетської освіти;

3) використання англійської мови для забезпечення дисциплін логічного, політологічного й культурологічного циклів, спрямованих на формування загальних компетентностей.

Наукова новизна. Розроблена адаптована до сучасних національних і міжнародних умов практична модель функціонування філософських дисциплін і дисциплін соціогуманітарного блоку у структурі освітніх програм підготовки фахівців за спеціальністю „Публічне управління та адміністрування“, що дозволяє підвищити ефективність і конкурентоспроможність вищої освіти України в галузі публічного адміністрування, інтегрувати підготовку державних службовців і управлінців України в міжнародний освітній і науковий простір, створити умови адаптації інституціональних і неінституціональних управлінських практик України до стандартів Європейського Союзу.

Практична значимість. Використання отриманих результатів в освітній практиці університетів України, що здійснюють підготовку фахівців за спеціальністю „Публічне управління та адміністрування“", дозволяє підвищити якість вищої освіти, а також знайти оптимальне рішення проблеми співвідношення фундаментальної та вузькоспеціалізованої складових підготовки державних службовців і керівників.

Ключові слова: громадське управління та адміністрування, філософські дисципліни, вища освіта України, підготовка управлінців

\section{Роль философских дисциплин в образовательных стратегиях подготовки специалистов в отрасли публичного администрирования}

\author{
С. В. Руденко ${ }^{1}$, О.А. Базалук ${ }^{1}$, В. Ф. Цвых 1 , \\ И. П. Кальмук $\kappa^{1,2}$
}


1 - Киевский национальный университет имени Тараса Шевченко, г. Киев, Украина, e-mail: rudenkosrg@gmail.com 2 - Киевский университет права НАН Украины, г. Киев, Украина, e-mail: kalmukip@gmail.com

Цель. Раскрыть оптимальную модель функционирования философских дисциплин в структуре образовательных программ подготовки специалистов по специальности „Публичное управление и администрирование“, а также связанные с этим аспектом особенности управления образовательными стратегиями подготовки государственных служащих. Авторы акцентируют внимание на: 1) способах управленческого решения проблемы перенасыщенности образовательных программ в отрасли публичного управления и администрирования блоком философских дисциплин; 2) адаптации образовательных программ подготовки специалистов в отрасли публичного администрирования к потребностям национальных и международных работодателей; 3) особенностях интернационализации образовательных программ в отрасли публичного администрирования в контексте академической мобильности и адаптации системы публичного администрирования Украины к стандартам Европейского Союза.

Методика. Авторы использовали метод культурно-исторического анализа, сравнительный метод, структурно-функциональный метод, а также метод экспертной оценки.

Результаты. Предложена организационная модель функционирования философских дисциплин в структуре образовательных программ подготовки специалистов в отрасли публичного администрирования, согласно которой дисциплины историкофилософского направления, блока теоретической и практической философии, которые преподаются на украинском языке, заменяются англоязычными учебными курсами блоков логики, теории аргументации, прикладной политологии и прикладной культурологии. Авторы выделили и рассмотрели связанные с местом и функциями философских дисциплин особенности управления образовательными стратегиями подготовки государственных служащих в Украине, которые в настоящее время требуют особого внимания:

1) перенасыщенность образовательных программ историко-философскими дисциплинами, а также дисциплинами отрасли теоретической и практической философии в условиях неудовлетворенной потребности формирования общих компетентностей;

2) необходимость адаптации образовательных программ подготовки специалистов в отрасли публичного управления и администрирования к потребностям национальных и международных работодателей без утраты преимуществ классического университетского образования;

3) использование английского языка для обеспечения дисциплин логического, политологического и культурологического циклов, направленных на формирование общих компетентностей.

Научная новизна. Разработана адаптированная к современным национальным и международным условиям практическая модель функционирования философских дисциплин и дисциплин социогуманитарного блока в структуре образовательных программ подготовки специалистов по специальности „Публичное управление и администрирование“, которая позволяет повысить эффективность и конкурентоспособность высшего образования Украины в отрасли публичного администрирования, интегрировать подготовку государственных служащих и управленцев Украины в международное образовательное и научное пространство, создать условия адаптации институциональных и неинституциональных управленческих практик Украины к стандартам Европейского Союза.

Практическая значимость. Использование полученных результатов в образовательной практике университетов Украины, которые осуществляют подготовку специалистов по специальности „Публичное управление и администрирование“, позволяет повысить качество высшего образования, а также найти оптимальное решение проблемы соотношения фундаментальной и узкоспециализированной составляющих подготовки государственных служащих и управленцев.

Ключевые слова: публичное управление и администрирование, философские дисциплины, высшее образование Украины, подготовка управленцев

Рекомендовано до публікації докт. філос. наук Г. С. Аляєвим. Дата надходження рукопису 18.02.18. 